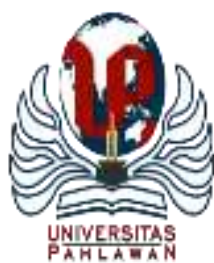

Edukatif : Jurnal Ilmu Pendidikan Volume 3 Nomor 5 Tahun 2021 Halm 3229 - 3242

EDUKATIF: JURNAL ILMU PENDIDIKAN

Research \& Learning in Education

https://edukatif.org/index.php/edukatif/index

\title{
Pengaruh Work From Home (WFH) terhadap Kinerja Karyawan pada Masa Pandemi COVID-19
}

\author{
Nadya Safirasari Setiawan ${ }^{1 凶}$, Achmad Room Fitrianto ${ }^{2}$ \\ Universitas Islam Negeri Sunan Ampel Surabaya, Indonesia ${ }^{1,2}$ \\ E-mail : $\underline{\text { Safirasarinadya@gmail.com }}{ }^{1}$, ar.fitrianto@ uinsby.ac.id ${ }^{2}$
}

\begin{abstract}
Abstrak
Covid-19 mempengaruhi berbagai sektor terutama sistem ketenagakerjaan perusahaan. Pelaksanaan sistem kerja dari rumah menggunakan konsep kerja secara online dengan pengawasan atasan perusahaan. Karyawan melakukan kegiatan kerja melalui aplikasi media online, seperti: whatsapp, telegram, zoom, meet google, dan web resmi perusahaan. Penelitian ini bertujuan sebagai sarana informasi terkait pengaruh kerja dari rumah terhadap kinerja karyawan pada masa Covid-19. Penelitian ini menggunakan jenis penelitian kualitatif. Dalam proses pengumpulan data penelitian kualitatif, peneliti menggunakan metode trianggulasi data dan analisa data induktif. Peneliti menggunakan tujuh narasumber, yaitu: manajemen general affair, manajemen workshop, tiga karyawan workshop, dan dua karyawan technical publication pada badan usaha milik negara wilayah Juanda Sidoarjo. Hasil penelitian membuktikan, bahwa kerja dari rumah (work from home) memberikan pengaruh yang signifikan terhadap kinerja karyawan pada masa Covid-19. Karyawan merasakan tidak ada kebebasan seperti kerja dari kantor dan kurangnya efektivitas penerapan kerja dari rumah. Karyawan menggantungkan hasil kerja pada mesin perusahaan. Kinerja karyawan mengalami hambatan. Karyawan tidak bisa menyelesaikan pekerjaan secara cepat.
\end{abstract}

Kata kunci: kerja dari rumah, kinerja, Covid-19.

\begin{abstract}
Covid-19 affects various sectors, especially the company's employment system. Implementation of work from home system using the concept of online work with the supervision of company bosses. Employees perform work activities through online media applications, such as: whatsapp, telegram, zoom, meet google, and the company's official web. This research aims as a means of information related to the influence of work from home on employee performance during Covid-19. This research uses this type of qualitative research. In the process of collecting qualitative research data, researchers use data trianggulation methods and inductive data analysis. Researchers used seven sources, namely: general affair management, workshop management, three workshop employees, and two technical publication employees at state-owned business entities in juanda Sidoarjo region. The results of the study proved that work from home (work from home) has a significant influence on employee performance during Covid-19. Employees feel no freedom such as work from the office and the lack of effectiveness of the application of work from home. Employees rely on the company's machinery. Employee performance is hampered. Employees can't get the job done quickly.
\end{abstract}

Keywords: work from home, performance, Covid-19.

Copyright (c) 2021 Nadya Safirasari Setiawan, Achmad Room Fitrianto

$\triangle$ Corresponding author

Email : Safirasarinadya@gmail.com

DOI : https://doi.org/10.31004/edukatif.v3i5.1224

ISSN 2656-8063 (Media Cetak)

ISSN 2656-8071 (Media Online) 
3230 Pengaruh Work From Home (WFH) terhadap Kinerja Karyawan pada Masa Pandemi COVID-19 - Nadya Safirasari Setiawan, Achmad Room Fitrianto

DOI: https://doi.org/10.31004/edukatif.v3i5.1224

\section{PENDAHULUAN}

Pada tahun 2021, Negara Indonesia menghadapi masalah kesehatan Covid-19. Sugiyono mengartikan masalah sebagai perbedaan teori dengan kenyataan lapangan. James stoner menjelaskan, bahwa masalah situasi mempengaruhi proses pencapaian tujuan organisasi. Prajudi Atmosudirjo menjelaskan, bahwa masalah merupakan proses pencapaian tujuan melalui berbagai macam tantangan. Dorothy Craig mengatakan, bahwa masalah merupakan kondisi yang akan datang dan berdampak negatif (Afid Burhanuddin, 2013). Masalah menimbulkan perubahan. George dan Jones mendefinisikan perubahan sebagai tindakan perpindahan masalah dari kondisi sekarang menuju kondisi yang akan datang (George, n.d., 2012). Schermerhorn menjelaskan, bahwa perubahan memiliki komponen penggerak yang di sebut sebagai agen perubahan. Agen perubahan merupakan tanggung jawab setiap individu dalam mengubah pola perilaku yang ada pada setiap karakter dan kondisi sosial tertentu. Masalah dan perubahan mempengaruhi suasana lingkungan kehidupan manusia menjadi tidak kondusif. Covid-19 ditemukan di Kota Wuhan Negara Cina pertama kali pada akhir tahun 2019. Negara Indonesia mengalami penambahan jumlah kasus Covid-19, yaitu: 47.899 warga terinfeksi Covid-19, 864 warga meninggal karena Covid-19, dan 20.123 warga sembuh dengan riwayat penyakit Covid-19. Pada tanggal 11 Juli 2021, Negara Indonesia mengalami peningkatan kasus zona merah. Satuan tugas Covid-19 menjelaskan, bahwa angka zona merah Covid-19 mengalami peningkatan dari 96 wilayah menjadi 129 wilayah. Pulau Jawa merupakan kasus zona merah terbesar, seperti: Jawa Timur, Jawa Tengah, dan Jawa Barat (Nafilah, 2021). Pada tanggal 9 Februari 2021, Presiden Joko Widodo menetapkan peraturan tentang pengadaan vaksinasi bagi Masyarakat Indonesia. Vaksinasi merupakan usaha pemerintah dalam meminimalisir angka korban Covid-19. Program vaksinasi ditetapkan pada peraturan presiden No.99 Tahun 2020 (Rokom, 2021). Pengadaan vaksin menghasilkan efektifitas yang sedikit. Presiden Joko Widodo tetap memberlakukan kegiatan di rumah. Presiden Joko Widodo memberikan himbauan secara tegas kepada warga Negara Indonesia agar tetap patuh terhadap penerapan protokol kesehatan. Covid-19 mempengaruhi berbagai sektor terutama sistem ketenagakerjaan perusahaan. Kementrian ketenagakerjaan menjelaskan, bahwa 17.224 dari 873.090 perusahaan sektor formal menerapkan work from home (WFH) mulai tanggal 7 April 2020 (Jawahir, 2020). Perusahaan memberlakukan kerja di tempat kerja secara offline sebelum adanya Covid-19. Namun perusahaan menerapkan kerja secara online di rumah pada saat pandemi Covid-19. Presiden Joko widodo menginstruksikan penerapan kebijakan pemberlakuan pembatasan kegiatan masyarakat (PPKM) di luar rumah, seperti: bekerja, belajar, dan beribadah harus dari rumah. Instruksi Presiden Joko Widodo dapat mengurangi penyebaran virus Covid-19 yang bersumber dari kerumunan, interaksi sosial, dan kurangnya penerapan protokol kesehatan (Ihsanuddin, 2020). Covid-19 mempengaruhi kesehatan dan sistem pola kerja masyarakat Indonesia. Perusahaan mengharapkan karyawan dapat adaptasi dengan pola sistem kerja dari rumah, yaitu work from home (WFH). Joko Widodo selaku Presiden Indonesia mengeluarkan surat edaran tentang Kementrian Badan Usaha Milik Negara Nomor 81 Tahun 2019 tentang sistem kerja badan usaha milik negara dalam tatanan normal baru pada sistem ketenagakerjaan. Jika badan usaha milik negara (BUMN) menempati wilayah zona merah, maka perusahaan memberlakukan 25 persen dari jumlah pegawai work from office (WFO) dan 75 persen work from home (WFH). Jika perusahaan menempati wilayah zona kuning, maka perusahaan memberlakukan 50 persen dari jumlah pegawai work from office (WFO) dan 50 persen work from home (WFH) (Ika Suryani, 2021). Erick Tohir selaku menteri BUMN mengeluarkan surat edaran SE-12 /S.MBU/06/2021 tentang kebijakan pemberlakuan work from home (WFH). Surat edaran diberikan kepada sebelas sektor devisi, yaitu: staf khusus kementrian BUMN, pejabat pimpinan tinggi pratama, pejabat administrator, pejabat pengawas, pejabat fungsional, pelaksana, pegawai tidak tetap, pegawai honorer, staff khusus, dan pegawai lain dalam lingkungan kementrian badan usaha milik negara (BUMN). Erick Tohir menginstruksikan kepada seluruh karyawan BUMN agar selalu menjaga tiga hal, yaitu: kebersihan, kesehatan, dan penerapan protokol kesehatan. Protokol kesehatan dilakukan melalui 5M, yaitu: memakai masker, 
mencuci tangan, menjaga jarak, menjauhi keramaian, dan pembatasan interaksi sosial (Suparjo, 2021). Kegiatan work from home (WFH) menggantungkan pada sarana dan prasarana aplikasi media online, seperti: zoom, whatsapp group, google meet, dan telegram. Karyawan harus menguasai cara penggunaan aplikasi media online tersebut. Aplikasi media online dipengaruhi oleh jaringan data. Jika karyawan memiliki jaringan data bagus dan penguasaan aplikasi media online, maka kinerja karyawan tidak mengalami gangguan. Jika karyawan menghadapi gangguan jaringan data dan kurangnya pengetahuan pengoperasian aplikasi media online, maka kinerja karyawan mengalami hambatan. Karyawan mendapatkan tugas kerja melalui aplikasi google form dan zoom. Karyawan mengumpulkan hasil kerja melalui aplikasi drive google. Dalam proses pemberlakuan kerja dari rumah (work from home), perusahaan harus mengoptimalkan perkembangan kinerja karyawan. Perusahaan harus melakukan tiga tahapan, yaitu: proses perencanaan, memantau pelaksanaan kerja melalui aplikasi, dan pengevaluasian hasil kerja. Jika perusahaan mengoptimalkan hasil kinerja karyawan, maka sistem perusahaan tidak mengalami gangguan secara operasional dan pendapatan perusahaan. Penelitian peneliti bertujuan untuk menjawab empat rumusan masalah, yaitu: tahapan, keuntungan, kerugian, dan faktor keberhasilan dalam penerapan work from home.

Work from home (WFH) merupakan kegiatan kerja karyawan dari rumah. Kegiatan kerja dari rumah (work from home) merupakan usaha perusahaan dalam menjamin keamanan kesehatan karyawan dari wabah pandemi Covid-19 dan patuh terhadap peraturan pemerintah terkait kebijakan bekerja dari rumah (Rakha, 2021). Work from home memiliki tiga tahapan, yaitu: proses perencanaan, proses lapangan, dan pengevaluasian hasil kerja. Penerapan work from home memiliki lima konsep perencanaan, yaitu: hubungan keluarga, sikap profesionalitas, keseimbangan kerja, penggunaan aplikasi media online, dan patuh pada aturan pemerintah. Pada tahap proses lapangan, perusahaan harus memperhatikan tujuh konsep, yaitu: pangsa pasar berfokus pada segmentasi pasar baru, berkerjasama dengan berbagai relasi mitra, peduli terhadap kebutuhan masa depan konsumen, inovasi jasa, adanya panduan manajemen resiko. Perusahaan melakukan enam konsep dalam tahap pengevaluasian hasil kerja, yaitu: proses kerja dilakukan sendiri, bersikap positif terhadap masalah yang muncul dalam proses kerja, perusahaan berusaha mencari penyelesaian masalah, adanya semangat yang tinggi, setiap tim atau karyawan memiliki sifat confidence dalam mengutarakan ide atau pendapat, adanya persamaan tujuan dalam mengejar target peluang, dan mengambil tindakan berani terhadap organisasi yang menghambat perusahaan. Keuntungan dan kerugian penerapan work from home (WFH) dipersepsikan melalui tiga sudut pandang dimensi, yaitu: dimensi ekonomi, dimensi teknologi, dan dimensi sosial. Karyawan mendapatkan lima manfaat dalam dimensi ekonomi, yaitu: bebas dalam penentuan jam kerja, kurangnya waktu perjalanan menuju kantor, berkurang biaya bensin, terhindar dari office politics, dan adanya peningkatan terhadap semangat, komitmen kerja, tingkat kepuasan karyawan, keahlian karyawan, dan pendapatan. Penerapan work from home dalam segi ekonomi memiliki tujuh kerugian, yaitu: tidak ada proses bertukar wawasan pengetahuan secara langsung, interaksi karyawan bergantung pada jaringan data, adanya kesalahpamahaman antar karyawan, langkah proses kerja karyawan bergantung pada jaringan sosial kantor, peningkatan biaya operasional rumah tangga, tidak ada dukungan suasana lingkungan kerja, serta duplikasi peralatan kerja di rumah dan di kantor. Dalam segi teknologi, karyawan mendapatkan manfaat penerapan work from home (WFH) berupa penerimaan informasi dari luar kantor. Karyawan mendapatkan informasi pendukung kerja dari berbagai perspektif dengan jangkauan lebih luas. Penerapan work from home (WFH) memiliki tantangan bagi karyawan dalam segi teknologi, yaitu: kecepatan kualitas internet sesuai dengan zona wilayah tempat tinggal, minimnya alat pendukung kerja, keamanan data informasi perusahaan dapat terancam, kecepatan perkembangan teknologi menghambat proses kerja karyawan, hasil kerja kurang optimal, dan munculnya fenomena urban sprawl. Karyawan mendapatkan empat keuntungan dalam faktor dimensi sosial, yaitu: urusan kepentingan pribadi dapat cepat teratasi, dapat meminimalisir tingkat stres akibat kemacetan jalan, kurangnya biaya pengasuh anak, dan dapat aktif kontribusi kegiatan komunitas daerah rumah. Dalam dimensi sosial, karyawan merasakan tingkat kesulitan dalam membagi waktu kerja dengan kepentingan 
pribadi dan jam waktu kerja lebih panjang. Jika karyawan melaksanakan kerja di kantor secara offline, maka jam kerja karyawan disesuaikan dengan ketentuan jam operasional perusahaan. Jika proses kerja karyawan dilaksanakan di rumah, maka jam kerja karyawan mengalami peningkatan lebih panjang (van Doremalen et al., 2021). Kerja dari rumah (work from home) memiliki lima faktor keberhasilan, yaitu: konsep perencanaan sistem kerja terarah, memperkuat sistem komunikasi, pengadaan training manager, sosialisasi sistem alur penerapan kerja dari rumah (work from home), dan evaluasi sistem efektivitas penerapan kerja dari rumah (Susanti et al., 2021).

Kinerja merupakan hasil kerja karyawan dalam mencapai tujuan organisasi (Fathia, 2021). Hasibuan menjelaskan, bahwa kinerja merupakan proses penyelesaian tugas perusahaan sesuai dengan tanggung jawab karyawan. Kinerja dapat memperlihatkan kualitas dan kuantitas yang di raih oleh karyawan. Pada saat pandemi, kinerja karyawan sangat dipengaruhi oleh faktor sarana dan prasarana kerja, pemantapan karyawan dalam pengoperasian aplikasi online, dan ketepatan pengumpulan hasil kerja sesuai dengan perencanaan. Kasmir menjelaskan, bahwa kinerja karyawan dipengaruhi tiga belas faktor, yaitu: rancangan kerja, pengetahuan, skill karyawan, motivasi kerja, gaya kepemimpinan, kepemimpinan, kepribadian, budaya organisasi, kepuasan kerja, lingkungan kerja, loyalitas, komitmen, dan disiplin kerja (Narande \& Kasmir, 2017). Pemberlakuan kebijakan kerja dari rumah (work from home) dirasakan oleh perusahaan daerah Juanda Sidoarjo. Pihak manajemen melakukan pembagian tugas kerja dalam mendukung program pembatasan kegiatan masyarakat. Karyawan tidak diberikan kebebasan dalam proses penentuan hari kerja. Dalam proses work from home, karyawan harus dapat dihubungi setiap waktu (stand by call). Pembagian hari kerja setiap karyawan dibedakan oleh pihak manajemen. Manajemen perusahaan mempertimbangkan faktor beban kerja setiap devisi. Ketika perusahaan membutuhkan karyawan dalam proses penyelesaian kerja mendesak, maka karyawan harus siap menangani pekerjaan di kantor. Meskipun karyawan memiliki status jadwal kerja work from home, karyawan harus memenuhi keinginan pimpinan perusahaan. Apabila karyawan sudah tidak memiliki batas waktu (dateline) pengumpulan hasil kerja, maka karyawan dapat melakukan kerja di rumah (work from home).

Karyawan melakukan interaksi dengan seluruh stakeholders melalui aplikasi zoom dan situs web resmi perusahaan. Situs web resmi perusahaan memperlihatkan absensi kehadiran dan hasil kerja. Absensi kehadiran dan hasil kerja karyawan merupakan tolak ukur kualitas kinerja. Kerja dari rumah (work from home) memiliki lima faktor keberhasilan, yaitu: konsep perencanaan sistem kerja terarah, memperkuat sistem komunikasi, pengadaan training manager, sosialisasi sistem alur penerapan kerja dari rumah (work from home), dan evaluasi sistem efektivitas penerapan kerja dari rumah (Susanti et al., 2021).

\section{METODE PENELITIAN}

Peneliti menggunakan metode penelitian kualitatif. Sugiono menjelaskan, bahwa metode penelitian kualitatif digunakan peneliti untuk meneliti objek penelitian bersifat alamiah (Agus Sugiyono, 2001). Dalam metode penelitian kualitatif, peneliti menggunakan metode pengumpulan data jenis trianggulasi dan analisis data induktif. Peneliti menggunakan pendekatan penelitian fenomenologi. Pendekatan fenomenologi dilakukan peneliti melalui dua tahapan, yaitu: sumber data sesuai dengan kenyataan lapangan dan pemahaman peristiwa pengaruh work from home (WFH) terhadap kinerja karyawan pada masa Covid-19. Metode fenomenologi memiliki sifat netral dan alamiah. Metode fenomenologi dapat mendeskripsikan permasalahan secara akurat tanpa memanipulasi data (Alase, 2017). Metode fenomenologi dapat menjelaskan kondisi pengaruh work from home (WFH) terhadap kinerja karyawan pada masa Covid-19.

Peneliti menggunakan tiga teknik pengumpulan sumber data, yaitu: observasi, wawancara dan dokumentasi. Teknik wawancara dan dokumentasi ditujukan kepada tujuh narasumber perusahaan daerah Juanda Sidoarjo, yaitu: satu manajemen general affair, satu manajemen workshop, tiga karyawan workshop, 
dan dua karyawan technical publication. Peneliti mendapatkan data sesuai dengan kejadian lapangan secara individual melalui teknik observasi dan wawancara. Sugiyono menjelaskan, bahwa wawancara merupakan teknik pengumpulan data secara tatap muka antara peneliti dengan narasumber. Peneliti menggunakan jenis wawancara terpimpin. Dalam konsep wawancara terpimpin, peneliti sudah menyiapkan daftar pertanyaan yang akan di tanya kepada narasumber. Hasil wawancara dipengaruhi oleh dokumentasi.

Dokumentasi merupakan metode pengumpulan data kualitatif melalui bukti dokumen yang ada pada perusahaan. Dokumen memiliki enam bentuk, yaitu: surat, catatan harian, cenderamata, laporan, atau foto. Meleong mengklasifikasikan dokumen menjadi dua, yaitu: dokumen harian dan dokumen resmi. Dokumen harian merupakan catatan seseorang secara tertulis tentang pengalaman yang terjadi. Dokumen resmi menggambarkan aktivitas keterlibatan perusahaan pada suatu komunitas tertentu. Dokumen resmi diklasifikasikan menjadi dua, yaitu: internal dan eksternal. Dokumen internal didapatkan peneliti, seperti: pengumuman, memo, instruksi, aturan suatu lembaga, pemberlakuan sistem perusahaan, atau hasil notulensi rapat pimpinan. Dokumen eksternal didapatkan peneliti melalui majalah, koran, buletin, buku, jurnal, artikel, atau surat pernyataan (Lusiana, 2021).

Peneliti menggunakan tiga jenis teknik analisis data, yaitu: reduksi data, penyajian data, dan kesimpulan (verifikasi). Reduksi data (Data Reduction) merupakan proses pemikiran peneliti melalui tingkat pemahaman. Reduksi data digunakan peneliti kualitatif untuk melihat masalah baru, masalah tidak di kenal, dan belum ada pola masalah. Proses reduksi data dilakukan peneliti melalui empat cara, yaitu: merangkum hasil wawancara, memilih hal pokok, mengambil data penting, dan kategorisasi. Reduksi data menghasilkan data yang jelas dan mempermudah peneliti dalam proses pengumpulan data selanjutnya. Penyajian Data (Data Display) menghasilkan tiga jenis data, yaitu: kejelasan data, data sistematis, dan pemahaman hasil data. Proses penyajian data menghasilkan teori grounded. Teori grounded dihasilkan secara induktif, melalui data lapangan, dan di uji melalui verifikasi data secara berlanjut. Kesimpulan dan Verifikasi (Conclusion Drawing and Verification) menghasilkan penemuan baru yang belum ada sebelumnya. Penemuan baru ditunjukkan melalui tiga bentuk, yaitu: teori, deskripsi, atau hubungan interaksi. Jika kesimpulan data tidak ditemukan bukti pendukung hasil penelitian, maka hasil penelitian menghasilkan perubahan data. Jika kesimpulan data ditemukan bukti pendukung hasil penelitian, maka hasil penelitian menghasilkan data kredibel. Kesimpulan dan Verifikasi (Conclusion Drawing and Verification) harus menemukan jawaban rumusan masalah. Peneliti menyeimbangkan antara jawaban narasumber dengan sumber penelitian yang di peroleh. Sumber penelitian mempengaruhi keabsahan hasil data peneliti.

\section{HASIL DAN PEMBAHASAN PENELITIAN}

Pada tanggal 31 Desember 2019, WHO China Country Office di Kota Wuhan menemukan pneumonia varian baru. WHO China Country Office menjelaskan, bahwa pneumonia varian baru merupakan corona virus. Corona virus dirasakan penduduk seluruh dunia. WHO (World Health Organization) menetapkan, bahwa virus corona merupakan penyakit darurat kesehatan dunia global (Public Health Emergency of International Concern) (Wangge et al., n.d., 2021). Corona virus merupakan penyakit saluran pernapasan manusia. Corona virus diawali dengan tiga gejala, yaitu: panas, batuk, dan bersin. Penyakit corona virus dapat disamakan dengan middle east respiratory syndrome (MERS) dan severe acute respiratory syndrome (SARS). Corona virus dinyatakan world health organization (WHO) dapat bertahan tiga hari di plastik dan tiga jam dalam aerosol (van Doremalen et al., 2021).

Covid-19 mempengaruhi sistem kerja perusahaan. Perusahaan menerapkan konsep work from home. Mustajab menjelaskan, bahwa work from home merupakan perubahan kegiatan kerja yang di alami oleh seluruh perusahaan pada masa pandemi Covid-19. Perubahan dibuktikan melalui sistem kerja. Karyawan tidak diperkenankan bekerja dan berkumpul pada satu ruangan kantor (Mustajab et al., 2020). Faktor utama 
pemberlakuan work from home dibenarkan oleh lima narasumber peneliti dari tujuh narasumber. Lima narasumber memiliki perbedaan devisi, antara lain: satu manajemen general affair, satu manajemen workshop, satu technical publication, dan dua karyawan workshop. Pemberlakuan kerja dari rumah (work from home) merupakan salah satu bentuk mendukung program pemerintah. Perusahaan mendapatkan surat perintah dari kementrian badan usaha milik negara. Pemberlakuan kerja dari rumah (work from home) tercipta berdasarkan situasi dan kondisi nasional yang genting. Penerapan kerja dari rumah memiliki empat tujuan, yaitu: dapat mengurangi kerumunan, mencegah penularan Covid-19 secara tidak langsung, pengurangan kegiatan kerja karyawan di luar rumah, dan menjaga kesehatan karyawan beserta keluarga. Kegiatan kerja di luar rumah dapat menimbulkan resiko tinggi. Mustabsat meyakinkan teori mustajab. Mustabsat menjelaskan, bahwa banyak perusahaan beranggapan penerapan kerja dari rumah (work from home) dapat tercipta produktivitas yang besar (Asbari et al., 2020). Kerja dari rumah (work from home) memiliki delapan indikator, yaitu: lingkungan kerja, gangguan stres kerja, hubungan dengan keluarga, waktu perjalanan, kesehatan dan keseimbangan kerja, kreativitas dan produktivitas tinggi, bersikap profesionalitas, dan tekanan diri (Farrell, n.d., 2021). Pada saat pandemi Covid-19, lingkungan kerja memberikan kesempatan kepada karyawan dalam memilih kapan, dimana, dan bagaimana dalam penyelesaian proses kerja. Pada tahap proses kerja, karyawan harus bisa mengendalikan tingkat emosionalitas. Tingkat emosionalitas karyawan mempengaruhi tingkat stres kerja setiap karyawan (Zebua \& Siahaan, 2021). Stres kerja disebabkan berbagai faktor, seperti: karyawan merasakan kesulitan dalam pengoperasian aplikasi online, dateline kerja yang terlalu pendek, dan masalah komunikasi antar karyawan. Stres kerja dapat dihindarkan melalui peran keluarga. Hubungan keluarga memiliki peran penting dalam mendukung aktivitas kerja dari rumah (work from home). Karyawan tidak memiliki jarak dengan keluarga. Jarak hubungan keluarga dapat disamakan seperti waktu perjalanan. Pada masa pandemi Covid-19, karyawan tidak menghadapi kemacetan jalan. Penerapan kerja dari rumah (work from home) tidak membutuhkan waktu perjalanan. Kerja dari rumah (work from home) memiliki tingkat fleksibelitas jam kerja yang tinggi. Stres kerja dirasakan oleh dua narasumber peneliti dari tujuh narasumber. Narasumber merupakan karyawan workshop. Mereka mengatakan, bahwa penerapan work from home memiliki efektifitas yang kurang. Kerja dari rumah menggantungkan pada jaringan data dan jarak. Jika jaringan data menghadapi masalah, maka hasil kerja karyawan mengalami hambatan. Jarak menimbulkan dua dampak, seperti: terhambatnya sistem komunikasi dan terhambatnya proses kerja. Narasumber lebih mengutamakan work from office dibanding kerja secara work from home. Pekerjaan narasumber menggantungkan pada sarana perusahaan. Narasumber tidak dapat mengerjakan pekerjaan secara cepat.

Virus Covid-19 mengharuskan semua karyawan untuk menjaga imunitas tubuh dalam bekerja. Karyawan harus memperhatikan kesehatan dan keseimbangan kerja. Kesehatan dan keseimbangan kerja mempengaruhi kreativitas dan produktivitas tinggi dalam proses penyelesaian konsep kerja. Pandemi Covid19 dapat dihindarkan melalui tiga hal, yaitu: pemahaman tentang urutan virus, pemberian vaksin halal, dan kebijakan karantina (Fitrianto, 2021). Pada proses penyelesaian konsep kerja, karyawan harus memiliki sikap profesionalitas dalam membagi waktu antara kepentingan pribadi dengan masalah kerja. Manajemen perusahaan daerah Juanda Sidoarjo membenarkan adanya penerapan menjaga kesehatan dan sikap profesionalitas karyawan dalam membagi waktu jam kerja dengan kepentingan pribadi. Penerapan kesehatan diterapkan melalui empat tahapan, yaitu: pemberian masker, pemberian hand sanitizer, pemberian sabun cuci tangan, dan ikut serta dalam program vaksinasi. Para karyawan mengutamakan kepentingan perusahaan. Karyawan memiliki tanggung jawab sesuai dengan arahan perusahaan. Setiap karyawan memiliki rasa tanggung jawab sesuai dengan tugas kerja setiap devisi.

Perusahaan menggunakan aplikasi media online, seperti: zoom, google meet, whatsapp, drive google, dan aplikasi web resmi perusahaan. Pemberlakuan work from home memiliki perbedaan dengan sistem kerja di kantor secara langsung. Perbedaan dibuktikan melalui jadwal jam kerja. Jika karyawan melaksanakan kerja di kantor secara offline, maka jam kerja karyawan disesuaikan dengan ketentuan jam operasional perusahaan. 
Jika proses kerja karyawan dilaksanakan di rumah, maka jam kerja karyawan mengalami peningkatan lebih panjang (Kementerian Perencanaan Pembangunan Nasional/ Bappenas \& Mungkasa, 2020). Perusahaan daerah Juanda Sidoarjo menggunakan aplikasi media whatsapp dan zoom pada saat work from home. Karyawan mengirimkan bukti foto hasil kerja di aplikasi media whatsapp group. Hasil kerja karyawan sudah terkoordinasikan melalui media whatsapp group. Jika karyawan merasakan kesulitan dalam proses kerja, maka karyawan mengirimkan masalah kerja kepada pihak atasan melalui whatsapp via japri. Karyawan menggunakan web resmi perusahaan dalam proses absensi kehadiran.

Joko Widodo memberikan himbauan kepada seluruh perusahaan agar sistem kerja melalui konsep work from home. Penerapan work from home diberlakukan dengan tujuan agar penanganan Covid-19 dapat maksimal. Presiden Indonesia menjelaskan, bahwa masyarakat Indonesia harus melakukan gotong royong dan saling tolong menolong pada masa pandemi Covid-19. Sikap gotong royong dan saling tolong menolong dapat memberikan perubahan baik bagi kepentingan bersama (Fajar \& Lutfi, 2018). Narasumber perusahaan BUMN daerah Juanda Sidoarjo membenarkan adanya konsep kerja gotong royong. Jika salah satu devisi mengalami kekurangan tenaga kerja karena karyawan sedang work from home, maka devisi lain berpartisipasi dalam proses penyelesaian kerja. Penerapan work from home menciptakan konsep sistem kerja secara merangkap.

Pemerintah menginstruksikan kepada seluruh perusahaan harus berpartisipasi pada konsep work from home. Pemerintah mengizinkan perusahaan dengan sistem work from office. Namun pemerintah tetap mewajibkan seluruh perusahaan dengan konsep work from home. Menteri kesehatan mengeluarkan surat Keputusan Nomor 9 Tahun 2020 tentang pedoman PSBB. Work from home (WFH) harus diterapkan pada semua kantor, kecuali instansi yang berpengaruh besar bagi kehidupan banyak orang (Inang, 2020). Perusahaan BUMN daerah Juanda Sidoarjo merupakan salah satu sektor jasa yang vital dan berpengaruh bagi kehidupan banyak orang. Perusahaan BUMN daerah Juanda Sidoarjo tidak dapat menerapkan work from home secara penuh karena sistem kerja bergantung pada mesin di kantor. Mesin tidak diizinkan di bawa pulang oleh pihak perusahaan. Jika karyawan membutuhkan mesin, maka karyawan harus mendatangi kantor sesuai dengan jadwal work from office yang ada.

Penerapan work from home menggunakan aplikasi media online, jaringan data, dan alat penunjang. Perusahaan diberikan kebebasan oleh pemerintah dalam pemilihan aplikasi online. Perusahaan bebas menggunakan berbagai macam platform aplikasi, seperti: zoom, google meet, whatsapp, drive google, dan telegram. Penggunaan platform aplikasi online membutuhkan jaringan paket data. Pemerintah memberikan bantuan paket data. Bantuan paket data dibuktikan melalui Surat Keputusan Menteri Keuangan Nomor 394/KMK/02/2020 tanggal 31 Agustus 2020. Keputusan Menteri Keuangan Nomor 394/KMK/02/2020 berisikan tentang tunjangan pulsa gratis di beri kepada pegawai work from home. Sri Mulyani mengklasifikasikan pembagian paket data menjadi tiga bagian, yaitu: pejabat eselon satu dan dua sebesar Rp.400 ribu per bulan dan pejabat setingkat eselon tiga sebesar Rp. 200 ribu per bulan (Mansur, 2020). Tujuh narasumber tidak membenarkan adanya bantuan paket data bagi perusahaan. Peneliti mewawancarai narasumber dari empat devisi, yaitu: tiga karyawan workshop, satu manajemen workshop, satu manajemen general affair, dan dua technical publication. Paket data menggunakan uang setiap individu. Manajemen general affair mengatakan, bahwa pemberian bantuan paket data hanya di beri kepada karyawan yang bekerja di instansi negeri seperti Aparatur Sipil Negara (ASN). Badan Usaha Milik Negara (BUMN) belum mendapatkan bantuan paket data untuk saat ini.

Perusahaan menerapkan tiga tahapan dalam proses work from home, yaitu: proses perencanaan, proses lapangan, dan pengevaluasian hasil kerja. Dalam proses perencanaan, perusahaan harus mengikuti aturan pemerintah. Pemerintah membedakan pemberlakuan kerja melalui zona wilayah. Jika badan usaha milik negara (BUMN) menempati wilayah zona merah, maka perusahaan memberlakukan dua puluh lima persen dari jumlah pegawai work from office (WFO) dan tujuh puluh lima persen work from home (WFH). Jika badan usaha milik negara menempati wilayah zona kuning, maka perusahaan memberlakukan lima puluh persen dari 
jumlah pegawai work from office (WFO) dan lima puluh persen work from home (WFH) (Ika Suryani, 2021). Tujuh narasumber membenarkan adanya pemberlakuan sistem kerja dua puluh lima persen work from office dan tujuh puluh lima persen work from home. Perusahaan BUMN daerah Juanda Sidoarjo menerapkan konsep kerja dua puluh lima persen work from office dan tujuh puluh lima persen work from home selama masa pemberlakuan pembatasan kegiatan masyarakat. Pihak perusahaan harus memenuhi himbauan pemerintah terkait pemberlakuan sistem kerja selama pandemi Covid-19.

Pihak perusahaan harus memperhatikan sarana dan prasarana karyawan selama proses work from home, seperti: pemberian bantuan paket data dan sosialisasi pengoperasian sistem aplikasi online. Jika karyawan memiliki jaringan data bagus dan penguasaan aplikasi media online, maka kinerja karyawan tidak mengalami gangguan. Jika karyawan menghadapi gangguan jaringan data dan kurangnya pengetahuan pengoperasian aplikasi media online, maka kinerja karyawan mengalami hambatan. Tujuh narasumber tidak menghadapi gangguan saat pengoperasian aplikasi media online. Karyawan dapat menyesuaikan perkembangan arus globalisasi. Pemahaman pengoperasian aplikasi media online dilakukan karyawan melalui konten tutorial pada platform aplikasi youtube dan hubungan dengan keluarga. Jika karyawan merasakan kesulitan pengoperasian aplikasi online pada masa work from home, maka karyawan melakukan komunikasi dengan pihak keluarga terutama anak.

Pada tahap proses lapangan, perusahaan harus memperhatikan tujuh konsep, yaitu: pangsa pasar berfokus pada segmentasi pasar baru, berkerjasama dengan berbagai relasi mitra, peduli terhadap kebutuhan masa depan konsumen, inovasi jasa, adanya panduan manajemen resiko, pemanfaatan sumber daya yang ada, dan perhatian terhadap intensitas konsumen. Manajemen resiko memiliki fungsi agar meminimalisir ketergantungan perusahaan terhadap lingkungan eksternal. Pada masa pandemi Covid-19, kesulitan ekonomi merupakan salah satu bentuk manajemen resiko. Manajemen resiko dapat mengantisipasi perubahan lingkungan yang terjadi (Fitrianto, 2021). Perusahaan dapat meningkatkan confidence melalui sistem pemasaran kolaboratif. Intensitas konsumen harus diperhatikan perusahaan agar tercipta hubungan baik dengan konsumen. Jika perusahaan dapat memanfaatkan sumber daya yang ada, maka perusahaan mendapatkan laba yang besar (Putri \& Irwansyah, 2020). Tiga narasumber peneliti menjelaskan tahap lapangan yang terjadi pada saat penerapan work from home. Perusahaan BUMN daerah Juanda Sidoarjo menerapkan konsep manajemen resiko. Namun pihak manajemen merasakan kesulitan dalam proses penerapan manajemen resiko. Pandemi Covid-19 mempengaruhi pendapatan jasa operasional penerbangan. Harga tiket pesawat mengalami kenaikan yang drastis. Masyarakat Indonesia banyak menggunakan transportasi lain sebagai alternatif. Manajemen perusahaan BUMN daerah Juanda Sidoarjo merasakan tidak semua konsep perencanaan dalam manajemen resiko terwujud. Namun pihak manajemen memiliki relasi kerja yang baik. Konsep pelayanan perusahaan tidak mengalami perubahan selama pandemi Covid-19. Devisi technical publication mengatakan, bahwa perusahaan tetap mempertahankan nama baik perusahaan dan kualitas hasil kerja. Karyawan perusahaan BUMN wilayah Juanda Sidoarjo mengerjakan pekerjaan sesuai dengan standar operasional prosedur yang ada.

Perusahaan melakukan enam konsep dalam tahap pengevaluasian hasil kerja, yaitu: proses kerja dilakukan sendiri, bersikap positif terhadap masalah yang muncul dalam proses kerja, perusahaan berusaha mencari penyelesaian masalah, adanya semangat yang tinggi, setiap tim atau karyawan memiliki sifat confidence dalam mengutarakan ide atau pendapat, adanya persamaan tujuan dalam mengejar target peluang, dan mengambil tindakan berani terhadap organisasi yang menghambat perusahaan (Susanti et al., 2021).

Pada saat pandemi Covid-19, Perusahaan BUMN daerah Juanda Sidoarjo melakukan evaluasi kerja berupa striping secara online. Striping online dilakukan sesuai dengan tahap perencanaan. Karyawan menggunakan whatsapp dan web resmi perusahaan. Perusahaan memiliki dua situs web resmi perusahaan, yaitu: merpati maintenance facility information system dan pt.mmf.co.id. Merpati maintenance facility 
information system berisikan data hasil kerja dan absensi karyawan. Situs pt.mmf.co.id merupakan informasi pelayanan jasa yang tersedia pada perusahaan.

Karyawan melakukan kerja sendiri. Pada saat pandemi Covid-19, karyawan memiliki etos kerja yang baik. Etos kerja baik diciptakan melalui persamaan tujuan karyawan dalam mencapai target peluang. Pihak karyawan beranggapan, bahwa target peluang dapat mensejahterakan kepentingan bersama. Perusahaan harus memiliki sifat proaktif. Proaktif merupakan tindakan pencegahan (preventive) perusahaan melalui tiga cara, yaitu: antisipasi masalah, antisipasi kebutuhan, dan antisipasi perubahan di masa depan melalui inovasi (Nurhidayati \& Si, n.d., 2020). Perusahaan daerah Juanda Sidoarjo melakukan dua tahapan dalam proses antisipasi masalah. Pihak manajemen memfokuskan pada lisensi perusahaan dan sertifikasi karyawan. Pihak manajemen mengatakan, bahwa perusahaan memiliki surat izin resmi yang terdaftar dalam menteri pertahanan. Perusahaan mengajukan approval surat izin resmi melalui beberapa persyaratan. Karyawan memiliki sertifikasi kerja resmi secara internasional seperti KAN. Karyawan harus memiliki sertifikasi dan pengalaman kerja. Pihak manajemen mempertahankan laba perusahaan dalam antisipasi kebutuhan. Jika laba perusahaan tidak mengalami masalah, maka kebutuhan operasional dapat terpenuhi. Pemenuhan kebutuhan operasional mempengaruhi kecepatan hasil kerja. Pihak manajemen mempelajari secara teknis terkait perusahaan dalam antisipasi perubahan di masa depan. Proses pembelajaran dilakukan agar pencapaian target dan konsep perencanaan dapat berjalan sesuai harapan.

Pada masa Covid-19, perusahaan harus memiliki karakteristik risk tasking. Risk tasking merupakan solusi perusahaan dalam masa tidak kondusif. Perusahaan dapat meningkatkan hasil laba melalui program risk tasking. Perusahaan memberikan motivasi terhadap karyawan dalam situasi yang menantang dan kreatif. Madsen menjelaskan, bahwa risk tasking memanfaatkan peluang segmentasi pasar untuk mencapai keuntungan yang tinggi (Ludvigsson, 2020). Risk tasking memiliki tiga karakteristik, yaitu: perusahaan senang menghadapi tantangan baru, berani melakukan inovasi baru dalam mencapai keuntungan besar dan adanya proyek berisiko tinggi. Pihak manajemen membenarkan adanya penerapan risk tasking pada perusahaan BUMN daerah Juanda Sidoarjo. Pihak perusahaan memiliki konsep kerja yang berisiko tinggi. Resiko tinggi dibuktikan melalui harga barang komponen pesawat konsumen. Jika karyawan melakukan kerja tidak teliti, maka komponen pesawat konsumen mengalami kerusakan yang lebih fatal dari sebelumnya. Perusahaan BUMN daerah Juanda Sidoarjo melakukan inovasi jasa berupa sistem pelayanan. Pihak manajemen perusahaan selalu meningkatkan konsep kerja karyawan dan kualitas hasil kerja agar sesuai dengan keinginan konsumen. Manajemen perusahaan menghadapi tantangan baru dalam proses pemasaran. Namun pihak manajemen menyikapi dengan senang. Tantangan baru dapat mendatangkan ilmu baru.

Work from home merupakan sistem kerja baru secara online di Negara Indonesia. Masyarakat Indonesia menghadapi tantangan dalam proses masa kerja work from home. Work from home mempengaruhi kinerja karyawan Indonesia. Jika karyawan memiliki rentang usia produktif, maka karyawan tidak mengalami kesulitan dalam proses kerja work from home. Jika karyawan memasuki usia tidak produktif, maka pemberlakuan work from home sangat mempengaruhi hasil kinerja (Fathia, 2021). Penerapan work from home memiliki keuntungan dan kerugian dilihat dari tiga dimensi, yaitu: dimensi ekonomi, dimensi teknologi, dan dimensi sosial. Karyawan mendapatkan lima manfaat dalam dimensi ekonomi, yaitu: bebas dalam penentuan jam kerja, kurangnya waktu perjalanan menuju kantor, berkurang biaya bensin, terhindar dari office politics, dan adanya peningkatan terhadap semangat, komitmen kerja, tingkat kepuasan karyawan, keahlian karyawan, dan pendapatan. Penerapan work from home dalam segi ekonomi memiliki tujuh kerugian, yaitu: tidak ada proses bertukar wawasan pengetahuan secara langsung, interaksi karyawan bergantung pada jaringan data, adanya kesalahpamahaman antar karyawan, langkah proses kerja karyawan bergantung pada jaringan sosial kantor, peningkatan biaya operasional rumah tangga, tidak ada dukungan suasana lingkungan kerja, serta duplikasi peralatan kerja di rumah dan di kantor. Dalam segi teknologi, karyawan mendapatkan manfaat penerapan work from home (WFH) berupa penerimaan informasi dari luar kantor. Karyawan mendapatkan 
informasi pendukung kerja dari berbagai perspektif dengan jangkauan lebih luas. Penerapan work from home (WFH) memiliki tantangan bagi karyawan dalam segi teknologi, yaitu: kecepatan kualitas internet sesuai dengan zona wilayah tempat tinggal, minimnya alat pendukung kerja, keamanan data informasi perusahaan dapat terancam, kecepatan perkembangan teknologi menghambat proses kerja karyawan, hasil kerja kurang optimal, dan munculnya fenomena urban sprawl. Urban Sprawl merupakan perkembangan kota yang meluas sampai pada wilayah pinggiran. Jika kegiatan kota mengalami kepadatan, maka fenomena urban sprawl muncul. Karyawan mendapatkan empat keuntungan dalam faktor dimensi sosial, yaitu: urusan kepentingan pribadi dapat cepat teratasi, dapat meminimalisir tingkat stres akibat kemacetan jalan, kurangnya biaya pengasuh anak, dan dapat aktif kontribusi kegiatan komunitas daerah rumah. Dalam dimensi sosial, karyawan merasakan tingkat kesulitan dalam membagi waktu kerja dengan kepentingan pribadi dan jam waktu kerja lebih panjang. Jika karyawan melaksanakan kerja di kantor secara offline, maka jam kerja karyawan disesuaikan dengan ketentuan jam operasional perusahaan. Jika proses kerja karyawan dilaksanakan di rumah, maka jam kerja karyawan mengalami peningkatan lebih panjang.

Lima narasumber dari tujuh narasumber merasakan keuntungan dan kerugian pada masa work from home. Karyawan mendapatkan tujuh keuntungan dalam penerapan work from home, yaitu: karyawan dapat istirahat di rumah, bertemu dua puluh empat jam dengan keluarga, gaji utuh, dapat terhindar dari paparan Covid-19, beban operasional perusahaan berkurang, hobi dapat berjalan beriringan dengan pekerjaan, dan mendukung program pemerintah terkait program work from home. Karyawan merasakan kerugian sesuai dengan tugas dan tanggung jawab setiap devisi. Devisi production merasakan enam kerugian, yaitu: karyawan adaptasi dengan jadwal kerja, sulit membagi antara kepentingan pribadi dengan kepentingan perusahaan, komunikasi bergantung pada kecepatan jaringan data, pekerjaan tidak dapat selesai dengan cepat, pekerjaan bergantung pada sarana kantor, dan waktu kerja tidak sesuai dengan jadwal yang ada. Devisi techhnical publication merasakan kerugian secara personal, seperti: bosan dan tidak bebas seperti work from office. Devisi manajemen merasakan lima kerugian, yaitu: perubahan ritme kerja, adanya oversupply, pemasokan berkurang, dan effort maksimal.

Kerja dari rumah (work from home) memiliki lima faktor keberhasilan, yaitu: konsep perencanaan sistem kerja terarah, memperkuat sistem komunikasi, pengadaan training manager, sosialisasi sistem alur penerapan kerja dari rumah (work from home), dan evaluasi sistem efektivitas penerapan kerja dari rumah (Susanti et al., 2021). Kinerja merupakan kegiatan proses kerja karyawan dalam mencapai hasil kerja melalui beberapa tahapan dan kesepakatan prosedur kerja. Fahmi menjelaskan, bahwa kinerja merupakan proses kerja yang terukur melalui kesepakatan kerja (Carolina \& Natalia, n.d., 2020). Mangkunegara menjelaskan, bahwa kinerja merupakan hasil kerja melalui konsep kualitas dan kuantitas karyawan sesuai dengan tugas dan tanggung jawabnya (Waris, 2015). Robbins mengklasifikasikan indikator kinerja menjadi enam bagian, yaitu: kualitas, kuantitas, ketepatan waktu, efektivitas, kemandirian, dan komitmen kerja (Isvandiari \& Purwanto, 2018). Kualitas dapat menghasilkan hasil kerja melalui tingkat kemampuan setiap karyawan. Kualitas mempengaruhi kuantitas kinerja. Jika karyawan memiliki hasil kerja bagus, maka karyawan menghasilkan kuantitas kerja yang maksimal. Kuantitas kerja merupakan jumlah hasil kerja yang sudah di raih oleh karyawan dalam proses kerja. Dalam penyelesaian kerja, karyawan harus memperhatikan ketepatan waktu dan efektivitas kerja. Ketepatan waktu merupakan penyelesaian hasil kerja sesuai dengan kesepakatan. Tujuh narasumber mengatakan, bahwa mereka dapat menyelesaikan hasil kerja sesuai dengan dateline kerja. Namun karyawan melakukan effort yang sangat tinggi dibanding pada saat work from office. Karyawan merasakan stres kerja. Meskipun karyawan merasakan stres kerja, karyawan memiliki pola pikir yang tenang dan terarah. Pola pikir karyawan merupakan salah satu pola keberhasilan dalam mencapai kualitas dan kuantitas hasil kerja. Efektivitas merupakan pemanfaatan sumber daya yang ada dalam mendukung proses kerja. Penerapan kerja dari rumah (work from home) mengharuskan karyawan untuk bersikap mandiri dan komitmen dalam bekerja. Sikap kemandirian mempengaruhi hasil kerja. Jika karyawan dapat menyelesaikan kerja secara 
individual, maka karyawan memiliki tingkat kemandirian yang baik. Tingkat kemandirian karyawan mempengaruhi komitmen kerja. Jika karyawan memiliki komitmen kerja yang tinggi, maka karyawan memiliki rasa tanggung jawab dalam proses penyelesaian kerja. Karyawan perusahaan BUMN daerah Juanda Sidoarjo siap berkomitmen kepada perusahaan. Komitmen dibuktikan melalui pencapaian target kerja. Mereka melakukan usaha yang maksimal. Karyawan dapat memenuhi panggilan perusahaan setiap waktu (stand by call). Karyawan memahami kepentingan perusahaan. Jika perusahaan melakukan panggilan mendadak, maka karyawan tanggap dalam memenuhi panggilan perusahaan.

\section{KESIMPULAN}

Penelitian peneliti menghasilkan adanya pengaruh work from home terhadap kinerja karyawan secara signifikan. Peneliti ingin menemukan data terkait judul penelitian. Pihak manajemen badan usaha milik negara daerah Juanda merasakan tidak semua konsep perencanaan dalam manajemen resiko terwujud. Namun pihak manajemen memiliki relasi kerja yang baik. Karyawan tetap mempertahankan kualitas pelayanan selama pandemi Covid-19 dan kualitas hasil kerja. Penerapan work from home mengalami pengurangan tenaga kerja di kantor. Jika salah satu devisi mengalami kekurangan tenaga kerja karena karyawan sedang work from home, maka devisi lain berpartisipasi dalam proses penyelesaian kerja. Penerapan work from home menciptakan konsep sistem kerja secara merangkap. Karyawan tidak merasakan kebebasan dalam aktivitas kerja dari rumah. Penerapan work from home memiliki efektivitas yang kurang. Peneliti mengharapkan tulisan penelitian dapat bermanfaat bagi perusahaan dengan sistem kerja work from home.

Peneliti memiliki tiga saran, yaitu: pengembangan inovasi jasa, penambahan karyawan lapangan, dan mengubah strategi dalam mencapai perencanaan manajemen resiko. Pihak perusahaan sebaiknya mengembangkan inovasi jasa perbaikan pesawat menjadi kargo. Pada saat pandemi Covid-19, jasa kargo mengalami peningkatan yang cukup signifikan. Perusahaan sebaiknya melakukan penambahan karyawan lapangan seperti devisi workshop enggineering agar terhindar dari sistem konsep kerja merangkap selama penerapan work from home. Pihak manajemen harus melakukan perubahan dalam strategi manajemen resiko. Pihak manajemen sebaiknya melakukan teknik analisis SWOT (Strenght, Weaknesses, Opportunities, and Threats).

\section{DAFTAR PUSTAKA}

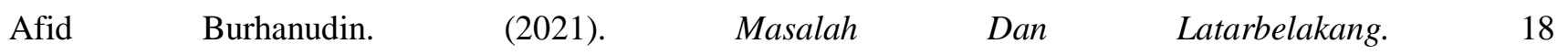
Juli.Https://Afidburhanuddin.Files.Wordpress.Com

Agus Sugiyono. (2001). Metodologi Ekonomi Positivisme. Https://Doi.Org/10.13140/2.1.4065.9841

Alase, A. (2017). The Interpretative Phenomenological Analysis (Ipa): A Guide To A Good Qualitative Research Approach. International Journal Of Education And Literacy Studies, 5(2), 9.Https://Doi.Org/10.7575/Aiac.Ijels.V.5n.2p.9

Anam. (2021). Webinar Manajemen Bisnis Di $\quad$ Era $\quad$ Pandemi $\quad$ Covid-19. 4 Agustus.Http://Research.Unissula.Ac.Id.

Asbari, M., Novitasari, D., Silitonga, N., Sutardi, D., \& Gazali, G. (2020). Mempertahankan Kinerja Karyawan Di Masa Pandemi Covid-19: Studi Kasus Pada Industri Ritel. Jmk (Jurnal Manajemen Dan Kewirausahaan), 5(3), 183. Https://Doi.Org/10.32503/Jmk.V5i3.1093

Carolina, V., \& Natalia, M. (N.D.). Karakteristik Eksekutif Terhadap Tax Avoidance Dengan Leverage Sebagai Variabel Intervening. 18, 11. 
3240 Pengaruh Work From Home (WFH) terhadap Kinerja Karyawan pada Masa Pandemi COVID-19 - Nadya Safirasari Setiawan, Achmad Room Fitrianto

DOI: https://doi.org/10.31004/edukatif.v3i5.1224

Dian Erika. (2021). Wfh Sudah Setahun Diserukan Jokowi, Kasus Covid-19 Masih Terus Bertambah.1 Agustus. Https://Amp.Kompas.Com/Nasional/Read /2021/03/15/11020621/Wfh-Sudah

Setahundiserukan-Jokowi-Kasuscovid- 19-Masih-Terus Bertambah

Fajar, M. A., \& Lutfi, I. (2018). Pengaruh Trait Kepribadian (Personality) Dan Dukungan Sosial Terhadap Risk Taking Behavior Pada Pendaki Gunung. Jurnal Pengukuran Psikologi Dan Pendidikan Indonesia (Jp3i), 6(2). Https://Doi.Org/10.15408/Jp3i.V6i2.9162

Farrell, K. (N.D.). Working From Home: A Double Edged Sword. 27.

Fathia, W. (2021). Pengembangan Tes Kinerja Pada Materi Teks Negosiasi Dan Teks Debat Mata Pelajaran Indonesia Berbasis Konteks Budaya Lokal Sumatera Barat. 3(6), 11.

Fitrianto, A. R. (2021). Sustainable Livelihood Approach Addressing Community's Economic Distress Facing The Covid 19 Outbreak: A Methodological Concept: International Conference On Business And Engineering Management (Iconbem 2021), Surabaya (Online), Indonesia. Https://Doi.Org/10.2991/Aebmr.K.210522.009

George, J. M. (N.D.). Feeling Good-Doing Good: A Conceptual Analysis Of The Mood At WorkOrganizational Spontaneity Relationship. 20.

Ihsanuddin.(2021). Jokowi: Kerja Dari Rumah, Belajar Dari Rumah, Ibadah Di Rumah Perlu $=$ Digencarkan. 19 Juli. Https://Nasional.Kompas.Com/Read/202 0/03/16/15454571/Jokowi-Kerja-DariRumah-Belajar-Darirumah-Ibadah-Di- Rumah-Perlu-Digencarkan?Page=All

Ika Suryani.(2021). Rincian Aturan Terbaru Ppkm Mikro Mulai 22 Juni. 3 Agustus.Https://Www.Suarasurabaya.Net /Kelanakota/2021/Rincian-Aturan Terbaru-Ppkm-MikroMulai-22-Juni/

Inang. (2021). Covid-19 Belum Juga Berakhir, Lebih Baik Wfh Atau Wfo?. 3 Agustus.Https://Indonesiaterhubung.Id/ Artikel/526/Covid-19-Belum-Juga- Berakhir-Lebih-Baik-WfhAtau-Wfo

Isvandiari, A., \& Purwanto, A. (2018). Pengaruh Budaya Organisasi, Disiplin Kerja, Dan Kepuasan Kerja Terhadap Kinerja Karyawan Non Medis Rumah Sakit Islam Malang. Jurnal Ilmiah Bisnis Dan Ekonomi Asia, 11(1), 38-43. Https://Doi.Org/10.32812/Jibeka.V11i1.29

Jawahir Gustav Rizal. (2021). Pandemi Covid- 19, Apa Saja Dampak Pada Sektor Ketenagakerjaan Indonesia?.19 Juli. Https://Www.Kompas.Com/Tren/Read/20 20/08/11/102500165/Pandemi-Covid19apa-Sajadampakpada-Sektor Ketenagakerjaan-Indonesia-?Page=All

Kementerian Perencanaan Pembangunan Nasional/Bappenas, \& Mungkasa, O. (2020). Bekerja Dari Rumah (Working From Home/Wfh): Menuju Tatanan Baru Era Pandemi Covid 19. Jurnal Perencanaan Pembangunan: The Indonesian Journal Of Development Planning, 4(2), 126-150. Https://Doi.Org/10.36574/Jpp.V4i2.119

Ludvigsson, J. F. (2020). Systematic Review Of Covid-19 In Children Shows Milder Cases And A Better Prognosis Than Adults. Acta Paediatrica, 109(6), 1088-1095. Https://Doi.Org/10.1111/Apa.15270

Lusianaoktaviani. (2021). Penelitian Kualitatif (Metode Pengumpulan $\quad$ Data). $10 \quad$ Juni. Https://Fitwiethayalisyi.Wordpress.Com/ Teknologi-Pendidikan/Penelitian Kualitatif-Metode Pengumpulan-Data/

Mansur. (2021). Bunyi Sk Menteri Jokowi Sri Mulyani Tentang Paket Kuota Internet Gratis Bagi Asn/Pns Dan Mahasiswa. 3 Agustus. Https://Makassar.Tribunnews.Com/2020 /09/01/Bunyi-Sk-Menteri-JokowiSri- Mulyani-Tentang-Paket-Kuota-Internet- Gratis-Bagi-Asnpns-Dan-Mahasiswa

Mustajab, D., Bauw, A., Rasyid, A., Irawan, A., Akbar, M. A., \& Hamid, M. A. (2020). Working From Home Phenomenon As An Effort To Prevent Covid-19 Attacks And Its Impacts On Work Productivity. Tijab (The International Journal Of Applied Business), 4(1), 13 Https://Doi.Org/10.20473/Tijab.V4.I1.2020.13-21 
3241 Pengaruh Work From Home (WFH) terhadap Kinerja Karyawan pada Masa Pandemi COVID-19 - Nadya Safirasari Setiawan, Achmad Room Fitrianto

DOI: https://doi.org/10.31004/edukatif.v3i5.1224

Nafilah Sri Sagita. (2021). Zona Merahcovid-19 Meledak Jadi $129 \quad$ Wilayah. $18 \quad$ Juli. Https://Health.Detik.Com/Berita- Detikhealth/D-5642544/Zona-Merah- Covid-19-Meledak-Jadi-129 Wilayah

Narande, A. A. G., \& Kasmir, K. (2017). Peran Budaya Organisasi Dan Manajemen Pengetahuan Terhadap Kinerja Aparatur. Manajerial, 9(1), 1. Https://Doi.Org/10.31479/M.V9i1.16

Nova Dwi Prasetiyo. (2021). Pengertian Observasi Penelitian Kualitatif. 10

Juni. Http://Novadwiprasetiyo.Blogspot.Com/ 2011/11/Pengertian-Observasi Penelitian.Html

Nurhidayati, M., \& Si, M. (N.D.). Jurusan Ekonomi Syariah Fakultas Ekonomi Dan Bisnis Islam Institut Agama Islam Negeri Ponorogo 2020. 106.

Nuryanti. (2021). Pandangan Para Ahli Soal Work From Home Langkah Pemerintah Untuk Menekan Penyebaran Corona. 20 Juli. Https://M.Tribunnews.Com/Amp/Corona/ 2020/03/19/Pandangan-ParaAhli-Soal- Workfromhome-Langkah-Pemerintah-Untuk-Menekan-Penyebaran-Corona?Page=2

Putri, A. V., \& Irwansyah, I. (2020). Communication Patterns And Media Technology Role In Organization And Society During Pandemic. The Journal of Society And Media, 4(2), 228 Https://Doi.Org/10.26740/Jsm.V4n2.P228-261

Rakha Fahreza. (2021). Wfh Artinya Konsep Pekerjaan Yang Dikerjakan Di Rumah Ketahui Untung Ruginya. 20 Juli. Https://Www.Merdeka.Com/Jatim/Wfh- Artinya-Konsep-Pekerjaan-Yang- Dikerjakan-DiRumahketahui-Untung- Ruginya-Kln.Html

Ridandi Bintang Pamungkas. (2021). Work From Home: Kelebihan Kekurangan Dan Tips Untuk Menjalaninya. 22 Juli. Https://Www.Niagahoster.Co.Id/Blog/Wo Rk-From-Home/

Rokom. (2021). Pemerintah Perbarui Aturan Pelaksanaan Vaksinasi Covid-19. 19 Juli.Https://Sehatnegeriku.Kemkes.Go.Id /Baca/Beritautama/20210613/0337893/ Pemerintahperbaruiaturanpelaksanaan- Vaksinasicovid-19/

Salmaa Awwaabiin. (2021). Metode Penelitian Kualitatif: Pengertian Menurut Ahli, Jenis- Jenis, Dan Karakteristiknya. 9 Juni. Https://Penerbitdeepublish.Com/Metode Penelitian-Kualitatif/

Suparjo. (2021). Erick Thohir Terbitkan Se Wfh Bagi Karyawan Kementrian Bumn. 20 Juli. Https://Www.Idxchannel.Com/Economi Cs/Erick-Thohir-Terbitkan-Se-Wfh-Bagi- KaryawanKementerian-Bumn

Susanti, R., Amelia, D. T., Damaiyana, F., \& Bernadine, O. R. (2021). Produktivitas Kerja Saat Work From Home (Wfh) Dan Work From Office (Wfo) Pada Dosen Fkm Universitas Mulawarman Di Masa Pandemi Covid-19. Jurnal Ilmiah Kesehatan Masyarakat: Media Komunikasi Komunitas Kesehatan Masyarakat, 13(1), 28-33. Https://Doi.Org/10.52022/Jikm.V13i1.172

Syafnidawaty. (2021). Data Primer. 10 Juni. Https://Raharja.Ac.Id/2020/11/08/Data-Primer/

Syafnidawaty. (2021). Data Sekunder. 10 Juni. Https://Raharja.Ac.Id/2020/11/08/Data-Sekunder/

Syafnidawaty. (2021). Metodologi Penelitian. 9 Juni. Https://Raharja.Ac.Id/2020/10/25/Metod OlogiPenelitian/

Tantri Dewayani. (2021). Bekerja Dari Rumah (Work From Home) Dari Sudut Pandang Unit Kepatuhan Internal. 22 Juli. Https://Www.Djkn.Kemenkeu.Go.Id/Arti Kel/Baca/13014/Bekerja-Dari-Rumah- WorkFrom-Home-Dari-Sudut-Pandang-Unit-Kepatuhaninternal.Html

Tommy. (2021). Pengertian Wawancara, Fungsi, Manfaat, Tujuan, Dan Struktur. 11 Juni. Https://Kotakpintar.Com/Pengertian- Wawancara-Adalah/

Van Doremalen, N., Letko, M., Fischer, R. J., Bushmaker, T., Yinda, C. K., Schulz, J., Seifert, S. N., Kim, N. J., Hemida, M. G., Kayali, G., Park, W. B., Perera, R. A., Tamin, A., Thornburg, N. J., Tong, S., Queen, K., Van Kerkhove, M. D., Choi, Y. K., Oh, M., ... Munster, V. J. (2021). Surface-Aerosol Stability And 
3242 Pengaruh Work From Home (WFH) terhadap Kinerja Karyawan pada Masa Pandemi COVID-19 - Nadya Safirasari Setiawan, Achmad Room Fitrianto

DOI: https://doi.org/10.31004/edukatif.v3i5.1224

Pathogenicity Of Diverse Mers-Cov Strains From 2012-2018 [Preprint]. Microbiology. Https://Doi.Org/10.1101/2021.02.11.429193

Wangge, M. C. T., Kua, M. Y., Rewo, J. M., Pare, P. Y. D., \& Dolo, F. X. (N.D.). Edukasi Pencegahan Covid-19 Melalui Pendampingan Pembuatan Serta Penggunaan Healthy Kit Produksi Lokal Rumah Tangga. 11.

Waris, A. P. M. Dan A. (2015). Effect Of Training, Competence And Discipline On Employee Performance In Company (Case Study In Pt. Asuransi Bangun Askrida). Procedia - Social And Behavioral Sciences, 211, 1240-1251. Https://Doi.Org/10.1016/J.Sbspro.2015.11.165

Zebua, S. N., \& Siahaan, E. (2021). Pengaruh Kecerdasan Emosional, Kreativitas, Dan Kemampuan Menyesuaikan Diri Terhadap Kinerja Guru Sma. 3(6), 11. 